\title{
Analysing Transitions in Intimate Relationships with Panel Data*
}

\author{
Michael Feldhaus, Richard Preetz
}

\begin{abstract}
Panel data on intimate relationships are becoming increasingly available, enabling a closer examination and deeper understanding of why and how they develop over time. The aim of this review is to illustrate to what extent demographic research has made progress in understanding the dynamics of intimate relationships by examining panel data. We focus on hypotheses about key transitions throughout the progression of intimate relationships, ranging from union formation up to cohabitation, marriage, divorce and repartnering. For every hypothesis, we will present findings from cross-sectional data and illustrate whether the use of panel data and longitudinal methods modified the previous understandings of transitions in intimate relationships.
\end{abstract}

Keywords: Intimate relationships - Panel data - Life course transitions · Cohabitation $\cdot$ Marriage $\cdot$ Divorce

\section{Introduction}

Over recent decades, tremendous societal changes have taken place regarding the development of intimate relationships over the life course. These include changes in union formation processes, increasing rates of living-apart-together relationships, cohabitation, separation or divorce, repartnering, and same-sex relationships, alongside the postponement and overall decreasing rates of marriage. Thus, trajectories of intimate relationships have become more complex and divergent in many countries (Elzinga/Liefbroer 2007; Billari/Liefbroer 2010; Perelli-Harris/Amos 2015).

A large body of research in Demography, Sociology, and related disciplines focus on these ongoing changes in order to uncover the mechanisms of partnership-related

This article belongs to a special issue on "Identification of causal mechanisms in demographic research: The contribution of panel data". 
dynamics. In this regard, the objective of collecting longitudinal data is to improve the analytical potential for investigating ongoing decision-making processes and dynamics for a better understanding of the underlying mechanism.

In this review, we focus on the research question, to what extent has demographic research made progress in understanding the dynamics of intimate relationships through applying longitudinal data? To address this question, we limit the topics and focus on key demographic outcomes, such as the transition to union formation, cohabitation, marriage, separation or divorce, and repartnering. We start with a brief overview of demographic facts and theoretical advancements for investigating intimate relationships. We then review major findings and achievements with regard to demographic transitions in the context of using panel data.

For this large field of research, not all findings from the past decades can be reported. We must explicitly admit that the presented results are in some way selective. Rather, the aim is to concentrate on a few key hypotheses that cover the full range of the progress of intimate relationships. Here, we focus on assumptions and research questions that have been extensively internationally studied over the past decades and have been affected by the rise of longitudinal data and modern causal statistical methods. We conclude with a critical summary.

\section{Theoretical approaches for changing trajectories in intimate relationships}

In recent decades, the occurrence, trajectories, and dynamics of partnership-related living arrangements have changed in many European countries. Terms such as "the retreat from marriage" or the "de-institutionalisation of marriage" (Cherlin 2004; Sass/er/Lichter 2020) summarise these demographic trends as a result of decreasing marriage rates, increasing divorce rates and higher shares of extramarital births. The dissemination of cohabitation is another key indicator of ongoing demographic change in Europe and Western countries (Sass/er/Lichter 2020; see also Andersson et al. 2017). Furthermore, the rates of consensual unions and repartnering after a separation or divorce has increased in European countries over the past decades (Gałęzewska et al. 2017). Taken together, these findings document tremendous changes in union formation and partnership trajectories in Europe, and we find similar developments, for example, in North America and Australia.

Looking at these demographic developments, questions as to the factors that explain these changes arise. Various theoretical explanations are discussed and used for framing ongoing changes. A very popular approach is known as the Second Demographic Transition (SDT, van de Kaa 1987; Lestheaghe 1995, 2010). SDT emphasises the ideational changes that have occurred from the 1950s and 1960s onwards. It describes a preference drift from material needs (subsistence, shelter, physical and economic security) to non-material needs (freedom of expression, participation and emancipation, self-realisation, and autonomy). This shift in needs occurred alongside a shift in values and attitudes, accompanied by greater tolerance for diversity and respect for individual choices. This led to a decline of 
traditional values, less social group adherence and cohesion, and more liberal laws and attitudes (e.g., toward divorce, non-marital births, sexuality, and pre-marital cohabitation) (Lesthaghe 2010).

These developments were accompanied by a more rational "utility evaluation" of cohabitation and marriage in terms of the welfare of both adult partners, an aspect which was accentuated in the New Home Economics approach (Becker et al. 1977; Becker 1991; Browning et al. 2014). New Home Economics and other related costbenefit or utility maximizing models were highly influential in explaining partnershiprelated behaviour and decision-making processes. These models particularly focused on men's and women's economic status (earnings, education, social status), financial independence, partnership-related investments (homeownership, children), gender differentiations, direct or indirect costs and benefits (e.g., Becker et al. 1977; Oppenheimer 1988; 1997; Kalmijn 2011, 2013). This approach arose in conjunction with the increase in female labour force participation, which has in turn been linked to trends of delayed or postponed marriage, low fertility, and increased union dissolution. These changes are also often discussed in the theoretical framework of changing gender relationships in the public and private spheres, described as the "gender revolution" (Goldscheider et al. 2015). The strong focus of cost-benefit approaches on a rational evaluation of partnership-related transitions has been criticised at times by pointing out that cohabitation or marriage are rather heart-over-head matters (Basu 2006). Billari and Liefbroer argue that more attention should be paid to emotions and other related indicators rather than focusing purely on utility evaluation (Billari/Liefbroer 2016).

As an extension of microsociological approaches, cross-national comparative studies surged in recent decades. These approaches recognise that partnershiprelated behaviour and decisions are embedded, shaped, or constrained by larger social, economic, and cultural conditions, including laws, local or national opportunity structures, economic conditions, and demographic variables. Related studies analyse country-specific or contextual indicators with regard to union formation, cohabitation, marriage, divorce, and repartnering (Lundberg et al. 2016; Cohen/Pepin 2018). Similarly, the life course approach places greater emphasis on the microfoundation of individual behaviour (Mayer 2009; Bernardi et al 2019). As a heuristic model, the life course approach helps modulate the occurrence, timing, spacing, and stopping of biographical transitions (such as union formation, marriage, fertility behaviour, and separation) with an emphasis on the interdependencies of life domains and their contextual influences.

Another strand of theories relevant to partnership behaviour and decisionmaking processes stems from Psychology. In many studies, the Theory of Planned Behaviour (TPB) (Ajzen 1991) is used for modelling biographical transitions (Billari) Liefbroer 2007). Behaviour is influenced by proximal (behavioural intentions and actual behaviour control) and other determinants (attitudes or beliefs, subjective norms, perceived behaviour control). There are also a number of exchange theory approaches that attribute the stability and satisfaction of intimate relationships to exchange processes and (pre-) marital investment. Other psychological approaches often focus on stress theoretical arguments, coping strategies, vulnerabilities, and 
the roles of personality traits. More recent developments emphasise that findings from cognitive and neurological research as well as from evolutionary biology must be taken into account, especially for partnership decisions (Bachrach/Morgan 2013; Lieberwirth/Wang 2014; Billari/Liefbroer 2016). Taken together, we can say that a bundle of theoretical approaches from various disciplines have been developed over the past 40 years and have been applied for analysing dynamics and ongoing biographical transitions on intimate relationships. These theoretical approaches are worth mentioning because they outline a broad range of explanations often used for partnership-related transitions.

\section{Methods, data innovations, and causality}

Regarding data and methods, available data sets for research on partnership dynamics have changed considerably. In many countries, panel studies have been implemented alongside official statistics, register data, and cross-sectional studies, or at least studies that explicitly take a life course perspective by collecting partnerrelated events and partnership-related trajectories. The collection of partnership histories since the 1970s has contributed considerably to broadening the focus of analysis. It is now possible to analyse partnership trajectories and episodes which mark different transitions (e.g. cohabitation, marriage, separation/divorce, repartnering, remarriage, etc.). Simultaneously, advances in statistical methods, such as Event History Analysis and various types of Panel Regression Models, have made considerable contributions to a better understanding of underlying causal relations and offering new perspectives on the progress of intimate relationships. Another important improvement was the collection of dyadic data. In many surveys, both partners are asked about their partnership, their intentions, emotions, dynamics - also from a longitudinal perspective. Here too, the existence of Longitudinal Dyadic Models has considerably expanded the scope of analysis (Kenny et al. 2006).

More generally, there is an extensive literature on causality from different academic disciplines, implying different answers or at least different emphases regarding the concept of causality (Bunge 1979; Spirtes et al. 1993; Pearl 2000; Woodward 2003; Opp 2010; Pearl et al. 2019). In his book about “Making Things Happen" Woodward (2003) argued that it is heuristically useful to think of explanatory and causal relationships as relations that are exploitable for manipulation and control. The guiding idea of the manipulability approach as an approach for a working definition of causation has the advantage of fitting a wide range of the social and behavioural science, which is well-documented and formally elaborated by Pearl et al. (2019; Woodward 2003; Pearl 2000). Many statistics textbooks have pointed out that correlation does not imply causation and that no statistical method can determine the causal story from the data alone (Pearl et al. 2019). Pearl et al. (2019) elaborate upon four items to get a clear picture of causality: (1) a working definition of causation, (2) a method to formally articulate causal assumptions, (3) a method to link the structure of a causal model to the data, and (4) statistical methods to draw conclusions from the combination of causal assumptions embedded in a model and 
the data. Put simply, causation is defined as follows: " $X$ is a cause of $Y$ if $Y$ listens to $X$ and decides its value in response to what it hears" (Pearl et al. 2019: 5).

Having no deterministic laws in social science, we must refer to indeterministic causation, which means that a manipulation of $X$ changes the probability distribution of $Y$. In the deterministic case, changes of $X$ always lead to the same changes of $Y$. However, if causal relationships are indeterministic, a relevant equation has to specify the causal assumptions and, therefore, the direct causes of $X$ variables on a probability distribution of $\mathrm{Y}$. In the indeterministic context, this approach comes along with a bundle of criteria that must be considered in order to estimate the unbiased causal effect of a set of variables (Woodward 2003: 43; Pearl 2000): One widely accepted indicator that $X$ is a cause of $Y$ is based on time: The change of $X$ must occur before $Y$, which can be ensured by an intervention in experimental research or by collecting longitudinal data in a non-experimental setting. The research question determines how temporally close the measurements of $X$ and $Y$ must be. Another point relates to how to measure the change in $\mathrm{X}$. There is broad literature in social statistics regarding how changes over time can be measured within persons on the individual level and/or between persons (Brüderl 2010; Andreß et al. 2013). For example, while the fixed effects approach focuses on within-variation, random effect models include both within- and between-variation. Measuring changes in $X$ and related changes in $Y$ on the individual level is closer to causality and an experimental design than an overall correlation of cross-sectional data is. Furthermore, measuring causal relationships also depends on the set of included variables. We often do not know all determinants of $Y$, or we do not have appropriate measurements in the data. Therefore, it could be that we have omitted explanatory variables and therefore unobserved heterogeneity or a specific kind of selection, which leads to biased estimates. In this case, our conclusions on causality claims of $X$ among $Y$ may be wrong, as $X$ is related to important unknown or not included variables.

These criteria can be readily implemented in experimental designs in particular. Here, the sample is randomly divided into two or more groups, one of which is assigned an intervention while another is not. Alternatively, this procedure can be approximated with longitudinal data, when the change of $X$ proceeds the measurement of $Y$ and where the assumption is that both variables are randomly distributed. Compared to these approaches, the use of cross-sectional data does not seem to be an appropriate design for assessing causality due to omitted variable bias and the lack of the possibility of modelling changes in $X$ and $Y$ (Andreß et al. 2013). Keeping these general criteria of causality in mind, we next describe the progress of causality-based research for selected hypotheses in partnership research. Here, we will focus on key hypotheses about the progress of intimate relationships ranging from union formation to further transitions such as cohabitation, marriage, divorce, and repartnering. For each hypothesis, we will present previous findings from cross-sectional studies and discuss whether these initial findings are supported by the more recent the application of longitudinal data and causal methods. 


\section{$4 \quad$ Findings from Longitudinal Data}

\subsection{Union Formation and Living-Apart-Together}

Today, individuals may have a choice between numerous romantic options, including entering into casual short-term sexual relationships, living as a non-cohabiting couple in separate households, entering into stable cohabitation without marriage, or being a married couple with a joint household (Sass/er 2010). Contrary to the increasing postponement of marriage, there is no general trend in postponing union formation. For Germany, Konietzka/Tatjes (2014) show that men born in the early 1980s started their first partnership about one year earlier in life than those born in the early 1970s. However, for women, no differences by birth cohort are observed. For the US, Manning et al. (2014) found no delay in median age at first union for men and women in the same timeframe. Research about union formation often focuses on the influence of socio-economic resources, resulting in findings that higher outcomes in education and employment are associated with higher chances of entry into a partnership (Klein 1990; Bracher/Santow 1998; Oppenheimer 2003; Jalovaara 2012; Rapp 2018). However, in the following, we will discuss two main hypotheses in the field of union formation and living apart together as the main type of partnership after individuals start their unions.

\section{Do imbalanced partner markets affect union formation?}

The composition of partner markets, usually measured as the relative number of men and women (Sex Ratio), has been emphasised as a key theoretical factor for starting a new relationship (Becker 1991; Blau 1994; South et al. 2001; Stauder 2008). Chances and opportunities of forming cross-sex associations are hypothesised to be determined by the numerical distribution of men and women in the population. Thus, the partner who is in scarce has higher chances and opportunities of finding a partner. Studying these partner market effects has a long tradition going back to the 1920s (Groves/Ogburn 1928; Cox 1940). Several studies show significant effects of being the scarcer sex and higher rates of marriage (Trovato 1988; Fossett/Kiecolt 1991; South/Lloyd 1992; Angrist 2002; Schacht/Kramer 2016). All of these studies analyse marriage, rather than being in a relationship of any type, as the outcome. Only the study by Warner et al. (2011) investigates young adults' chances of being in a relationship depending on partner market imbalances with combined US census and cross-sectional survey data. They find no correlations between relationship status and sex ratios for men and women.

These previous studies theoretically assume a causal link between partner market imbalances and union formation through a time-ordered mechanism, in that imbalances result in different subsequent partnership outcomes. However, these studies do not use longitudinal data and methods that take this time-dependent relationship into account. Rather, they use cross-sectional data correlating the relative number of men and women with marriage or union status, and are thereby not able to uncover to what extent partner market conditions indeed affect 
subsequent outcomes. A recent study by Eckhard/Stauder (2019) combines register data and longitudinal survey data from the German Socio-Economic Panel (GSOEP) to test how different partner market measures like sex ratios, availability ratios, and partner market density affect the transition into a partnership. They start with a sample of single persons and follow them over time to investigate how the different partner market measures affect later transition rates into a new partnership. Their piecewise-constant models show significant effects of the availability ratio for men and partner market density for women, but no effects for sex ratios like those used in previous cross-sectional studies. Another recent study by Filser/Preetz (2021) uses combined register and longitudinal survey data from the German Family Panel (pairfam) to investigate whether regional sex ratios and subjective perceptions of meeting more men or women are associated with, and result in, different transition rates into partnership. They model the assumed link between partner market and partnership outcomes with a sample of people who were initially not in a partnership and follow them over time. Here, partner market imbalances predict later partnership outcomes. While there is no general association between regional sex ratios and subjective perceptions of meeting more men or women, results from the longitudinal event history analysis show only weak effects of being the scarcer sex, measured with age-specific sex ratios, and having higher transition rates into a partnership for women. No significant effects are found for men. On the contrary, the use of the subjective partner market measure shows strong effects of perceiving to meet more people of one's own sex on rates of union formation, in that rates of transition into partnership decrease if someone meets more people of their own sex.

In sum, longitudinal data and longitudinal methods suggest that strong partner market effects on union formation identified in previous studies are based on crosssectional findings and therefore may not relate to causality. Recent longitudinal approaches show only a weak influence of changing partner markets on partnership formation and may relativise the strong assumed relationship between imbalanced partner markets and union formation. As recent findings have shown, one explanation for this weak association may be the missing link between the regional measurement of partner market imbalances and how individuals perceive and experience these imbalances subjectively in their daily life contacts.

\section{Is living apart together a more stable or more transitory type of partnership?}

Research on living apart together (LAT) relationships is relatively new, with a growing number of studies since the early 2000s due to the availability of new datasets and more detailed questionnaires. While many of these studies are based on different concepts, definitions, and meanings of living apart together, such as committed or long-distance relationships, they all focus on the same basic concept of intimate partners living in separate households. Several studies put the prevalence of LAT relationships between around 6 percent to 10 percent in Australia (Reimondos et al. 2011), Canada (Milan/Peters 2003), the US (Strohm et al. 2009), the UK (Haskey 2005), 
France (Régnier-Loilier et al. 2009), Germany (Asendorpf 2008), Sweden (Olàh et al. 2020) and Eastern Europe (Liefbroer et al. 2015). They show that living in an intimate relationship with separate households occurs throughout all stages of the life course and is not characteristic for a specific stage and phase in someone's partnership biography. The number of LAT couples is highest in early adulthood and decreases until the age of 40 , but becomes stable later in life when living apart together is seen as an alternative stable type of relationship, e.g. after a divorce in later life. Further studies use descriptive methods such as cluster-analysis to investigate different types of LAT relationships, identifying clusters from independence-seeking young adults up to older adults in post-family life stages (Lois/Lois 2012; Régnier-Loilier et al. 2009; Coulter/Hu 2017; Pasteels et al. 2017). Liefbroer et al. (2015) and Rhoades et al. (2009) analyse the reasons for living apart together and find that the majority of couples live in separate households because of practical constraints such as the partners' employment or financial situations, or the housing market. Only around 20 percent of LAT couples live apart for reasons of independence or not feeling ready yet.

These findings from cross-sectional studies have resulted in a debate and the key assumption that living apart together may be a "new" alternative partnership form to cohabitation and marriage. The results suggest the existence of a significant group of couples who live in a stable LAT partnership over time.

More recent studies have used longitudinal data to observe the progress of LAT couples and investigate the assumption of living apart together as a stable alternative relationship form. Several further factors that influence the development and transition of living apart together relationships have been identified. The studies mostly use longitudinal methods of time-discrete event history analysis, fulfilling the time assumption that the measurements of $\mathrm{X}$ must occur before $\mathrm{Y}$. For Germany, Dorbritz/Naderi (2012) and Lois/Lois (2012) analyse the progression of LAT couples in their mid-20s and mid-30s over one and two years with longitudinal data from the German Family Panel (pairfam). Their findings show that around half of LAT couples experience a transition to cohabitation or separation within two years. Results from France with data from the Generation and Gender Survey (GGS) confirm the transitory character of living apart together relationships, with only 22 percent of couples still living in the same LAT relationship after three years, and 12 percent after six years (Régnier-Loilier 2016). Further results show differences in relationship progression by age. While the share of stable LAT relationships is lowest for young adults aged 22-27 with 6 percent survival after three years, for older adults, LAT may indeed be a form of coupledom in its own right, with around one-third of couples still in their LAT relationship after six years (Régnier-Loilier 2016). Schnor (2015) uses retrospective data for partnership biographies from Germany, showing the highly transitory character of LAT relationships, with 98 percent of LAT relationships experiencing either a transition into cohabitation or separation within 10 years. A recent study by Bastin (2019) examines single mothers' partnerships and shows a share of 20 percent in the same living apart together relationship after three years.

Besides investigating the number of couples still in LAT relationships within different time periods, all of these studies also examine several factors that influence 
the transition of living apart together relationships to cohabitation or separation. Considering the time assumption, they model the influence of these factors in a time-delayed way, measuring $X$ before the occurrence of $Y$.

Starting with structural characteristics for the transition to cohabitation, results show higher transition rates for couples with educational homogamy, whereas transition rates for those couples with lower-educated men than women decrease (Dorbritz/Naderi 2012; Wagner et al. 2019). A transition to cohabitation is also less likely for those in education or still living in the parental household (Lois/Lois 2012; Wagner et al. 2019). Previous life course experiences such as having children from a previous partner or the number of previous relationships decrease the likelihood of moving in together (Wagner et al. 2019; Bastin 2019). Relationship dynamic factors show higher transition rates if relationship satisfaction is high, partners were introduced to each other's parents, and if partners have positive intentions for future cohabitation, marriage, and children (Dorbritz/Naderi 2012; Wagner et al. 2019).

Turning to the transition from living apart together to separation, those who state independence as their main reason for living apart together have higher chances of breaking up over time and lower chances of moving in together (Régnier-Loilier 2016; Lois/Lois 2012). Krapf (2018) uncovers the role of geographical distance for LAT relationship development and finds higher risks of separation for long-distance and higher transition rates to cohabitation for those in short-distance relationships. While lower relationship satisfaction increases the risk of separation, more nights spent together per week decrease separation risks (Dorbritz/Naderi 2012).

To sum up, the use of longitudinal data improves our understanding of living apart together relationships significantly. Instead of describing the prevalence and characteristics of LAT couples with cross-sectional data, using panel data allows the researcher to examine the partnership course and discover when, how, and for what reasons LAT couples experience various union transitions. A key assumption from early cross-sectional studies is that living apart together may be a stable alternative partnership form to cohabitation and marriage due to the rising levels of importance of independence to individuals. However, longitudinal studies have revealed the highly transitory character of non-cohabiting partnerships. The use of longitudinal data uncovers the nature of living apart together as a phase throughout partnership courses, usually followed by either cohabitation or separation. Besides these descriptive findings over time, some studies have explicitly focused on causal relationships, such as those trying to disentangle the rationale behind the transition to cohabitation or separation including the fear of losing autonomy as an important predictor. However, in many cases, the causal claims behind the findings are still unclear because of omitted variables, thus requiring more specification. For example: Why does the previous number of partnerships decrease the chances of a transition to cohabitation? While there are numerous plausible reasons (e.g., negative experiences with previous partners, unfulfilled expectations, ambivalent attachment styles, etc.), causal explanations remain unclear. Another example is the role of educational homogamy: Which features might coincide with educational homogamy, influencing $X$ and therefore the outcome $Y$ over time (e.g., similar income, similar expectations, similar leisure time activities, similar attitudes etc.)? 
More analysis that considers dyadic data with information from both partners is needed. Previous studies have considered structural couple characteristics such as age, education, or employment situation more closely than relationship dynamics due to data limitations. However, to uncover the underlying mechanisms, both partners' satisfaction, expectations, and future orientations must be taken into account. The data from the German Family Panel (pairfam) covers both partners that live in separate households, offering unique possibilities to use dyadic model approaches not only for structural but also for relationship dynamic characteristics (for examples of dyadic analyses on relationship dynamics with pairfam, see Johnson/Horne 2016; Finn et al. 2020; Yurkiw/Johnson 2021).

\title{
4.2 Cohabitation and Marriage
}

Over recent decades, a large number of studies have been published with regard to the transition to cohabitation and marriage. In this brief review, it is not possible to investigate all these developments. Therefore, we again concentrate on several key research questions and hypotheses that have been received particular scholarly attention.

\section{Is cohabitation a temporary step towards marriage, or an alternative?}

In Northern and Western European and North American countries, spread of consensual unions started in the 1970s (in Eastern Europe since the 1990s) (Sobotka/ Toulemon 2008). While cohabitation was initially seen as a deviant or avantgarde behaviour, it is now socially accepted in many countries. Theoretically, the diffusion of consensual unions was first embedded in the SDT framework (Lesthaeghe 2010), emphasizing that cultural shifts and economic development trigger entry into cohabitations and the "de-institutionalisation of marriage". Demographic research started to observe the diffusion of cohabitation primarily by analysing social indicators for a first description of this then-new phenomenon (e.g., Bumpass/ Sweet 1989; Rindfuss/VandenHeuve/ 1990). In 1989, Bumpass and Sweet wrote:

\begin{abstract}
"There is no single answer to whether cohabitation is a late stage of courtship or an early stage of marriage. It is the former for couples who are uncertain about their relationship but are considering marriage, the latter for those who would marry immediately were it not for some practical constraint, and neither for couples who do not want to marry each other." (Bumpass/Sweet 1989: 615)
\end{abstract}

The authors postulate and investigate key hypotheses on the spread of cohabitation and rationale for decreasing marriages rates in the US by using data from the National Survey of Families and Households (NSFH). With the measurement of relationship histories as well as attitudes towards cohabitation, marriage, and divorce, the NSFH data set offered a unique database for relationship transitions at the time. Some of the initial results from the NSFH are worth mentioning: The entry into cohabitation was most likely among women and those who did not complete 
high school, those whose family received welfare, and those who did not grow up in a nuclear family. These consensual unions generally did not last long because most cohabiting couples either married or separated within a few years. From these and other findings, the question arose as to whether cohabitation was a step towards marriage or an alternative to it. At the time, answers to this question were quite unclear, and the initial results were based only on cross-sectional findings.

Over the next 30 years, research on cohabitation and marriage increased dramatically. Life course data and longitudinal data offered the opportunity of analysing partnership biographies over time. Even rather descriptive methods such as Sequence Analysis, Cluster Analysis, and Latent Class Analysis allow the investigation of partnership trajectories over time and include other descriptive variables - the identification of specific partnership types or patterns. For the US, Casper/Bianchi (2002) proposed different types based on the couple's rationale for cohabiting, which included "precursor to marriage", "trial marriage", "co-residential dating", and "alternative to marriage". Di Giulio et al. (2019) find five patterns of cohabitation: "prelude to fast marriage and childbirth", "alternative to marriage", "temporary union", "prelude to childless marriage", "stable cohabitation". Similar research strategies with similar results are used and presented by Heuveline et al. (2003; Hiekel et al. 2014; Jalovaara/Fasang 2015; Fulda 2016).

The opportunity of looking at complete partnership trajectories in the context of panel data increases the analytical power of answering questions of timing, duration, and meaning of cohabitation compared to other partnership related transitions. From these findings, it can be summarised that over the past 30 years, cohabitation has increasingly become a heterogeneous experience, its meaning and function varying from a stepping-stone into marriage to a marital alternative, with great variability across countries (Manning/Smock 2005; Vespa/Painter 2011; Sobotka/ Toulemon 2008). However, this area of research remains rather descriptive. While the information of partnership trajectories and related descriptive indicators for specific subgroups is very important, it is only a first step towards a more elaborate causal analysis. Many papers stop at this descriptive level.

\section{Why cohabitate? Why still marry?}

Besides the descriptive investigation of partnership trajectories, a large number of studies have focused on indicators determining the entry into cohabitation or marriage.

One key hypothesis postulates that women with high economic resources and higher education are much more independent and therefore do not need to marry. In 1997, Oppenheimer noted that there were no empirical signs of this socalled women's independence effect: Women with attractive economic resources were not less likely to enter marriage (Oppenheimer/Lew 1995; Oppenheimer 1997). Until this time, support for the independence hypothesis was found only in cross-sectional aggregate-level studies. For example, McLanahan/Casper (1995) regressed the percentage of married women aged 25-29 on, among other variables, the percentage of women, also aged 25-29, who were working full-time year-round. 
They found that employment had a large negative effect on marital status, which was interpreted as a support for the independence hypothesis.

However, individual-level analyses of marriage formation using longitudinal data and event history analysis failed to support the hypothesis: Rather, the opposite is the case, as micro-level regression analyses show that more education, employment, earnings of women coincide with a higher rather than a lower propensity to marry (e.g., Oppenheimer/Lew 1995; Lichter et al. 2006). In his article about the "price of partnering", Clarkberg (1999) uses the National Longitudinal Study of the High School Class of 1972 (NLS-72), based on six waves with retrospective marriage and cohabitation histories of 12,841 participants and discrete-time event history models, in order to investigate the role of economic factors regarding the entry into cohabitation and marriage. Results indicate that relative income (how well an individual is doing compared to others in the same position), is strongly associated with the transition to marriage, but it is less so with the transition to cohabitation. Furthermore, there are disparate effects of employment instability: While instability is negatively associated with the transition to marriage, it is positively associated with the transition to cohabitation. This example underlines how results and hypotheses can change if the specification of a causal model is more precise regarding time, the specification of change, and the granularity of data.

While the independence effect is related to women's economic position, the socalled uncertainty hypothesis focuses on men (Oppenheimer 1988). The argument is that unstable careers, nonemployment, or low earnings imply uncertainty, which should coincide with a lower rate of union formation and a higher rate for cohabitation rather than marriage (Oppenheimer 2003). Xie et al. (2003) explore the relationship between economic potential and rates of entry into marriage and cohabitation. The results confirm that all five measures of earnings potential strongly and positively influence the likelihood of marriage for men, but not for women. Earnings potential does not affect entry into cohabiting unions for either men or women. Kalmijn (2011), using the European Community Household Panel (ECHP, with 13 countries, using discrete-time event-history analysis), confirms that men who are not yet settled in their career postpone union formation and that cohabitation is less sensitive to economic insecurity than marriage is (see also, e.g., Liefbroer 2005; Robert/Bukodi 2005; Lichter et al. 2006). Therefore, there is some evidence that cohabitation is the "poor man's marriage", and there are empirical indications that changes in an individual's economic position are causally related to partnership-related transitions.

In many cases, contextual factors regarding the entry into cohabitation or marriage are analysed by comparing different countries (Kalmijn 2013). Multilevel analyses show that the direction and strength of the gradient depend on the societal context. In countries where gender roles are traditional, more highly-educated women are less likely to be married than women with lower levels of education; in gender-egalitarian countries, better-educated women are more likely to be married. For men, the educational effect on marriage is absent in traditional countries but becomes positive as gender roles become more equal (Dykstra/Poortman 2010). 
Concerning the theory of the Second Demographic Transition, Clarkberg et al. (1995), investigate whether attitudes affect the transition to cohabitation or marriage. Using event history techniques, they show that the choice between cohabitation and marriage is affected by attitudes and values towards work, family, leisure time-use, money, and gender roles, as well as values and attitudes toward marriage itself. Similar results using event history techniques were also previously found by Axinn/Thornton (1992). Billari/Liefbroer (2016) emphasise the role of cognitive and affective evaluations in the decision-making process to marry. Using panel data from the Panel Study on Social Integration in the Netherlands (PSIN) and cox hazard regression, the timing of entry into marriage was estimated. The key finding is that the affective evaluation of marriage and cohabitation is a better predictor of the actual entry into marriage than the cognitive evaluation, suggesting that the choice to enter marriage is more strongly dependent on emotions than rational considerations. Simultaneously, cognitive evaluations were found to be more influential for higher educated young adults than for young adults with a low level of education.

Another advantage of using panel data is related to analysing the timing of transitions. For example, in a recent paper, Sass/er et al. (2018) concentrate on the question of how rapidly women progress into cohabitation. What factors are associated with the tempo of shared living, and is the timing into cohabitation associated with subsequent marital transitions? Multivariate analyses (event history analysis) reveal important social class disparities in the timing of cohabitation. There is a rapid tempo to shared living among women from less-advantaged backgrounds, consistent with qualitative and quantitative research (Sass/er/Miller 2011; Sass/er et al. 2016). Women who enter into cohabiting unions rapidly may view living together as a more intensive form of dating or as an alternative to being single, as well as a means to take advantage of factors formerly touted as benefits of marriage. Sass/er et al. (2016) do not find evidence that those who rapidly moved in with their current partners also accelerated their pace into marriage. Instead, their findings suggest that rapid transitions into cohabitation may reduce the odds of transitioning into marriage, although these results are only weakly significant (see also Perelli-Harris) Amos 2015). These examples show that statistical techniques, especially Event History Analysis, have been used extensively to identify the factors that may explain a transition or the timing into cohabitation or marriage over time but with more or less precise measurement of changing $X$ variables. In many analyses, the variables used are often placeholders for assumed underlying mechanisms.

The dyadic perspective also has substantial advantages over the use of longitudinal data, because panel data offers the possibility to analyse the decisionmaking process to cohabitate or to marry from both partners' points of view. In this regard Duvander/Kridah/ (2020) investigate how decisions are taken regarding marriage among Swedish cohabiting couples. The study finds that women's and men's intentions to marry seem to be equally important, but that there are gendered differences by educational level: women's intentions carry more weight among highly educated couples, while men's intentions carry more weight among couples with lower levels of education. 


\section{Is there a "cohabitation effect"? Does marriage increase well-being?}

A burgeoning literature has explored whether there is a causal or spurious association between marriage and well-being, and whether pre-marital cohabitation positively or negatively affects subsequent marital outcomes (Musick/Bumpass 2012; James/Beattie 2012; Stanley et al. 2010). In this regard, a number of outcomes was analysed: physical and mental health, sexual fulfilment, family violence, job productivity, economic well-being, and contact with parents and friends (PerelliHarris/Styrc 2018; Soons/Kalmijn 2009; Musick/Bumpass 2012; Zimmermann/ Easterlin 2006).

Early results showed that cohabiting unions result in poorer outcomes. Axinn/ Barber (1997) demonstrated that individuals who cohabit prior to marriage for longer periods of time experienced an erosion of valuing marriage and childrearing over time. Thus, the experience of cohabitation may erode the motivation for and the commitment to marriage, and increase the tolerance for divorce. Further findings show that cohabitation comes along with poorer communication, lower relationship satisfaction, higher levels of domestic violence, and later divorce (e.g., Cohan/ Kleinbaum 2002; Dush et al. 2003; Kline et al. 2004; Stanley et al. 2004). Therefore, a hypothesis often investigated is known as the "cohabitation effect" (Stanley et al. 2006), indicating that pre-marital cohabitation leads to poorer marital outcomes. Two fundamental explanations, which may also be at work simultaneously, are discussed (Axinn/Thornton 1992; Brown/Booth 1996; Smock 2000): (a) the argument of selection means that the cohabitation effect exists because of the pre-existing characteristics of people who choose to cohabit, and (b) that cohabitation is a special kind of experience, i.e., that there is something about cohabitation itself that increases the risk for partnership dissatisfaction, distress, and divorce.

Results from longitudinal analyses indicate that differences in outcomes are reduced or eliminated upon accounting for selection into either cohabitation or marriage (James/Beattie 2012; Musick/Bumpass 2012; Perelli-Harris/Styrc 2018). Variables such as religious beliefs, attitudes about marriage and divorce, and other socio-demographic variables, associated with both the likelihood of cohabiting prior to marriage and difficulties in marriage, are included in many studies, and findings indicate that these selection variables explain some or all of the pre-marital cohabitation risk (e.g., Brown et al. 2006). Nevertheless, numerous studies show that selection does not completely explain the risk associated with cohabiting prior to marriage (e.g., Dush et al. 2003; Stafford et al. 2004; Kline et al. 2004; Stanley et al. 2006).

Recent studies using fixed-effects models for analysing within-variation over time show opposite effects, indicating that the transition to marriage per se results in few if any improvements in relationship quality. The authors found the similarities between marriage and cohabitation to be more striking than the differences: Entering into any union improved psychological well-being but reduced contact with parents and friends. Direct marriage and marriage preceded by cohabitation were statistically indistinguishable in all outcomes examined, providing no evidence that pre-marital cohabitation has negative consequences for well-being or ties to 
family and friends. When union dissolutions were excluded from the analysis, there were no statistically significant differences between the married and cohabiting for depression, relationships with parents, contact with parents, or time spent with friends (Musick/Bumpass 2012). Vespa/Painter (2011) extend research on the relationship between wealth accumulation and union experiences, such as marriage and cohabitation. Using longitudinal data, their findings indicate that marriage is positively correlated with wealth accumulation: Individuals who marry their one and only cohabiting partner experience a wealth premium that is twice as large as that for married individuals who never cohabited prior to marrying. Furthermore, some studies using longitudinal data indicate that relationship quality declines with union duration (e.g., Brown 2004; Umberson et al. 2005; Zimmermann/Easterlin 2006; Soons et al. 2009), showing a "honeymoon effect" in subjective well-being following marriage. Such analyses, which consider couples' well-being immediately before and after a transition or change, are only possible with appropriate panel data (see the contribution by Gattig/Minkus 2021 in this SI).

These are very important results, but we must note that research regarding the specific impacts of a biographical transition on future outcomes in many cases does not go behind the given associations over time. It is not the status of cohabitation or marriage itself, but rather the underlying partnership dynamics arising from or amplified by that status (e.g., stress and daily hassles, communication, common activities). Some papers discuss these aspects in their theoretical framework, but the variables are then not specified later in the model. For causal explanation, the link between a causal model, related variables, and available data is sometimes not sufficient or could be improved by using richer data.

\subsection{Divorce, Repartnering and Remarriage}

As divorce rates have increased, the investigation of reasons and consequences of separation and divorce has become a central topic in family research, first in the USA and also in European countries (Goode 1956). After a period of sharp increases in Europe since the 1970s, rates of divorce have begun to stabilise or even decline in nations with some of the highest levels, a phenomenon that suggests the possibility of a widespread stabilisation of divorce at a moderately high plateau (Cherlin 2017; Härkönen 2014).

\section{Are there changing impacts of education and employment on divorce over time?}

In initial studies, a number of socio-demographic characteristics (such as age at marriage, education, pregnancy, religion, parental divorce, children, employment, income, ethnic differences, etc.) hypothesised to make divorce more likely were first examined with cross-sectional data (e.g., Udry 1966; Bumpass/Sweet 1972; Becker et al. 1977). Many of the topics dealt with at the time remain relevant today (Raley/ Sweeny 2020). In his review, Amato (2010) identified nine consistent predictors of divorce: teenage marriage, poverty, unemployment, low educational attainment, 
pre-marital cohabitation, pre-marital fertility, interracial marriage, previous divorce, and parental divorce. In recent years, the analysis of the causes and outcomes of divorce has become much more differentiated: Teachman (2010), using the panel data of the NLSY-79, found that women's higher incomes and higher income ratios act to destabilise marriages, whereas cumulative labour market participation acts to stabilise marriages. Sayer et al. (2011) use longitudinal data to assess distinct predictors of wives and husbands leaving marriages. They find that when men are not employed, either spouse is more likely to leave. When wives report betterthan-average marital satisfaction, their employment affects neither spouse's exit. However, when wives report below-average marital satisfaction, their employment makes it more likely they will leave. The authors' findings suggest that theories of divorce require a "gendering" to reflect asymmetric gender dynamics. With regard to the uncertainty hypothesis and using Finnish register data, Jalovaara (2013) finds that lower levels of education, unemployment (of the man in particular), and the male partner's (or the couple's) low income increased dissolution rates of cohabitation and marriage. The stabilizing effects of each partner's high educational level as well as the male partner's employment and high income were stronger in marriage than in cohabitation.

With the availability of long-term panel data, such as the PSID or the SOEP, it is also possible to examine changes over longer periods with panel analysis. In this regard, Schwartz/Gonalons-Pons (2016) find that wives' relative earnings were positively associated with the risk of divorce among couples married in the late 1960s and the 1970s. Using discrete-time event-history techniques on data on first marriages from the Fertility and Family Surveys (FFS), Härkönen/Dronkers (2006) find that women with higher education had a higher risk of divorce in France, Greece, Italy, Poland, and Spain, but not in Estonia, Finland, West Germany, Hungary, Latvia, Sweden, and Switzerland. In Austria, Lithuania, and the United States, the educational gradient of divorce is negative. They find that the de-institutionalisation of marriage and unconventional family practices are associated with a negative educational gradient of divorce, while welfare state expenditure is associated with a more positive gradient (see also Matysiak et al. 2014). Therefore, with regard to the educational influence on divorce, Raley/Sweeny (2020) conclude that the argument that increased educational attainment reduces divorce risk by reducing financial hardship and stress, and by increasing marital quality, stands on weak empirical ground. More research on this potential link is needed.

\section{Does pre-marital cohabitation increase divorce risk?}

Previous findings indicate that pre-marital cohabitation was associated with a higher risk of martial dissolution (Bumpass/Sweet 1989), though it was unclear whether this was a selection effect or whether the cohabitation experience itself indeed destabilises marriage. New panel data and statistical tools can better disentangle this cohabitation-divorce association. Pre-marital cohabitation may increase the risk of divorce by truncating the marital search: couples may begin cohabiting without giving much consideration to long-term compatibility and then marry out of inertia or 
in response to a pregnancy (Stanley et al. 2006). Furthermore, there is also be an age effect: the younger a couple is when they begin living together, the more likely they are to eventually divorce (Kuperberg 2014). A growing body of evidence suggests that self-selection (rather than causal processes) is driving this statistical association (Brüderl/Kalter 2001; Impicciatore/Billari 2012). Findings by Kulu \& Boyle indicate that those who cohabit prior to marriage have a higher risk of marital dissolution. However, once observed and unobserved characteristics are controlled for, the risks of marital dissolution for those who cohabit prior to marriage are significantly lower than those who marry directly, which supports the "trial marriage" theory (Kulu/Boyle 2010). Some recent studies conclude that the association between premarital cohabitation and elevated risk of divorce may have weakened over time (Manning/Cohen 2012; Raley/Sweeny 2020). Looking at the US, since the mid-1990s, pre-marital cohabitation has not been associated with marital instability (Manning/ Cohen 2012). A meta-analysis found that pre-marital cohabitation was more strongly associated with marital stability as long as one married the first cohabiting partner (Jose et al. 2010). Once again, we must keep in mind that it is often not the status itself, but rather the underlying mechanism within a specific status, that is inducing these results. It seems that more research is needed regarding this question as well.

\section{Repartnering after a divorce}

Another example of the increasing use of panel data is the question of the occurrence and factors influencing repartnering and remarriage. Due to the increasing number of divorces, numerous studies have dealt with questions of remarriage in the US from the 1970s onwards (e.g., Sweet 1973; Becker et al. 1977). For example, Teachman/Heckert (1985) use marital histories, covered by the National Survey of Family Growth (1973), and compute life tables and proportional hazard models. Similar methods and estimates are used by Bumpass et al. (1990): They find that the presence and number of children, ethnic groups, women's age at divorce, age at first marriage, presence of children (in some studies), higher socio-economic position of men, and lower socio-economic position of women, as well as regional differences, influence the probability of remarriage.

In the meantime, many of the earlier results have been supported and expanded upon by more recent studies (de Graaf/Kalmijn 2003; Gałęzewska et al. 2017). De Graaf/Kalmijn (2003) use life history data and calculate competing-risk models. They find less support for economic theories and related variables. With regard to cultural aspects, they find that women with more individualistic orientations are less likely to repartner. This effect is primarily a rejection of marriage after divorce, not a rejection of cohabitation. Stronger support is obtained for the role of meeting and mating opportunities. Findings show that men and women who are more integrated into society are more likely to repartner. On the other hand, dependent children are also likely to restrict women's meeting opportunities as they increase the cost of time women spend searching for a new partner (de Graaf/Kalmijn 2003; Ivanova et al. 2013). Poortman (2007) computes frailty models and finds that chances of repartnering are smaller than chances of first union formation. Formerly married 
persons are less likely to enter a new union than former cohabiters are. Findings also indicate that "the first cut is the deepest": Union formation probabilities drop substantially after the first union dissolves but remain constant after subsequent break-ups. Using data from the Divorce in Flanders Study, Ivanova et al. (2013) analyse the impact of parenthood on repartnering. They find that full-time residential parents are the least likely to start a new union following separation and that parents are more likely to start a union with another parent than with a childless partner. Schnor et al. (2017) demonstrated that Flemish mothers with sole custody were less likely to repartner than those with shared custody, indicated that parenthood may not be a particularly attractive status on the partner market (e.g., Gałęzewska et al. 2017; Ivanova et al. 2013).

A further special topic is remarriage or repartnering after a "gray divorce", a divorce at age 50 or older (Brown et al. 2019): There is an increasing rate of gray divorces over the past few decades, but little is known about the mechanisms undergirding decisions to repartner after gray divorce. Brown et al. (2019) examined women's and men's likelihood of forming a marriage or cohabiting union following gray divorce by estimating competing risk multinomial logistic regression models using discrete-time event history data. About 22 percent of women and 37 percent of men repartnered within 10 years after a gray divorce. Repartnering more often occurred through cohabitation than remarriage, particularly for men. Resources such as economic factors, health, and social ties were linked to repartnering (Brown et al. 2019). The chances of men repartnering increase in higher income quintiles, whereas women in lower income quintiles are more likely to repartner, in opposite to women in higher income groups, who are less likely to do so (Pastee/s/Mortelmann 2017)

Another important influencing factor receiving increasing attention is existing contextual factors. Contextual factors - such as social norms towards divorce and remarriage, economic conditions, legal policies, welfare state regulations, the partner market, and the attractiveness of the separated women and men are important because they may influence the interplay between individual-level characteristics and repartnering behaviour, resulting in different associations across countries (Billari 2015). Current findings with longitudinal data confirm that there are many country-specific differences in this respect. Findings show that economic conditions, legal policies, and welfare state regulations influence women's need to repartner (de Graaf/Kalmijn 2003; Ivanova et al. 2013; Vanassche et al. 2015).

\section{Conclusions}

In this review, we have reviewed selected articles in order to analyse to what extent demographic research have made progress in understanding the dynamics of intimate relationships by applying longitudinal data. Given the wide range of studies and topics on intimate relationships, we focus on key demographic transitions: the entry into cohabitation, marriage, separation or divorce, and repartnering. Therefore, many studies and topics on partnership dynamics, such as the effects of 
various socio-cultural factors on partnership stability or the role of personal traits or personal constructs on partnership-related dynamics, are not considered here. We want to conclude our reflections on partnership relationships and their related transitions with the benefits that have emerged with the introduction of longitudinal data in regard to causal claims and the challenges that still remain.

Looking at studies on partnership-related transitions, we can conclude that significant initial studies have been carried out, particularly in the North American context. For example, the world's longest running household panel, the Panel Study of Income Dynamics (PSID), was launched in the USA in 1968. It is therefore not surprising that pioneering research is coming from North America. However, we can also emphasise that the foundations of longitudinal analyses have also improved considerably in European countries in recent decades.

Concerning partnership transitions (the entry into cohabitation, marriage, divorce, repartnering), life history data has introduced major improvements regarding the collection of complete partnership trajectories and related demographic events. Given complete partnership histories, it is now also possible to analyse different episodes, their duration, the timing or postponing, and resulting sequences over the life course, often differentiated by various cohorts. The simultaneous development of event data analysis, with its various possibilities, has led to a significant improvement of the time-based analysis of associations between variables over time. This was an essential step towards identifying causal relationships.

In subsequent years, event history data were more strongly supplemented by panel data, often based on annual surveys and rich data sets. These advances allowed for more accurate analyses over time and a much more precise detection of time-varying dependent and independent variables. Additional prospective information for analysing transition-related decision-making processes was also included with the newly-launched panel studies, such as intentions, attitudes, expectations, personality traits, etc. This has again considerably increased the potential of causal analysis because measurements of changes of dependent and independent variables are temporally closer and measured on the individual level over time. In this case, various panel regressions models (fixed-effects, randomeffects, dynamic panel models, latent growth curve modelling, etc.) are more likely to be used. Overall, these approaches are in line with the mentioned criteria about causality, and by applying these methods, our knowledge about causal claims within intimate relationships increases considerably.

Furthermore, the problems of omitted variables and unobserved heterogeneity as well as questions about selectivity bias are at least reduced given rich individual-level databases over long time periods. Therefore, we can conclude that the availability of longitudinal data, together with the improvement of statistical techniques, has led to a more precise analysis of causal claims regarding partnership dynamics and related transitions in recent decades.

However, some challenges remain: Careful attention must be paid to the link between the causal model and used data. In particular, this includes whether the measurement of a change in variable $X$ and the outcome $Y$ really represents the proposed and often theoretically justified underlying causal mechanism. Findings 
significant effects of, for example, gender, race, or partnership status, are in many cases not convincing or comparable with a manipulability approach of causal explanation. If we refer to causal relationships as relations that are exploitable for manipulation and control, strict causal analysis is essentially out of the question. Therefore, in many cases, the underlying mechanisms behind observed effects are of greater interest. In this regard, a rich database from different disciplines increase the options of examining assumed underlying mechanisms more directly.

Furthermore, longitudinal data are not a sufficient alternative for experimental designs. But with regard to the analysis of biographical transitions, conducting experimental studies is neither practically feasible nor ethically desirable. In this respect, questions of causality are perhaps difficult to answer conclusively.

In their recent review, Sharon Sass/er and Daniel Lichter conclude that

"the processes of union formation will become increasingly diverse, fragmented, and complicated. Family scholarship will be challenged as never before by these developments. International migration, racial and ethnic diversity, challenges to traditional gender relations and sexual identities, population aging, economic inequality, and new technologies, such as the internet and social media will increasingly reshape the mateselection process" (Sass/er/Lichter 2020: 48).

Of course, there is still enough to do, but if we expect that our findings offer more well-founded results for policy markers and practitioners, it is necessary to place greater emphasis on causal relations and related effect sizes: "It arguably has never been a better time to study the changing demographic, economic, or policy contexts of marriage." (Sass/er/Richter 2020: 41)

\section{References}

Ajzen, Icek 1991: The Theory of Planned Behavior. In: Organizational Behavior and Human Decision Processes, Theories of Cognitive Self-Regulation 50,2: 179-211. https://doi.org/10.1016/0749-5978(91)90020-T

Amato, Paul R. 2010: Research on Divorce: Continuing Trends and New Developments. In: Journal of Marriage and Family 72,3: 650-666. https://doi.org/10.1111/j.1741-3737.2010.00723.x

Andersson, Gunnar; Thomson, Elizabeth; Duntava, Aija 2017: Life-Table Representations of Family Dynamics in the 21st Century. In: Demographic Research 37,35: 1081-1230. https://doi.org/10.4054/DemRes.2017.37.35

Andreß, Hans-Jürgen; Golsch, Katrin; Schmidt, Alexander W. 2013: Applied Panel Data Analysis for Economic and Social Surveys. Berlin/Heidelberg: Springer-Verlag. https://doi.org/10.1007/978-3-642-32914-2

Angrist, Josh 2002: How Do Sex Ratios Affect Marriage and Labor Markets? Evidence from America's Second Generation. In: The Quarterly Journal of Economics 117,3: 997-1038. https://doi.org/10.1162/003355302760193940

Asendorpf, Jens B. 2008: Living Apart Together: Alters- und Kohortenabhängigkeit einer heterogenen Lebensform. In: KZfSS Kölner Zeitschrift für Soziologie und Sozialpsychologie 60,4: 749-764. https://doi.org/10.1007/s11577-008-0035-4 
Axinn, William G.; Barber, Jennifer S. 1997: Living Arrangements and Family Formation Attitudes in Early Adulthood. In: Journal of Marriage and Family 59,3: 595-611. https://doi.org/10.2307/353948

Axinn, William G.; Thornton, Arland 1992: The Relationship between Cohabitation and Divorce: Selectivity or Causal Influence? In: Demography 29,3: 357-374. https://doi.org/10.2307/2061823

Bachrach, Christine A.; Morgan, S. Philip 2013: A Cognitive-Social Model of Fertility Intentions. In: Population and Development Review 39,3: 459-485. https://doi.org/10.1111/j.1728-4457.2013.00612.x

Bastin, Sonja 2019: Single Mothers' New Partners: Partnership and Household Formation in Germany. In: Journal of Marriage and Family 81,4: 991-1003. https://doi.org/10.1111/jomf.12575

Basu, Alaka Malwade 2006: The Emotions and Reproductive Health. In: Population and Development Review 32,1: 107-121. https://doi.org/10.1111/j.1728-4457.2006.00107.x

Becker, Gary S.; Landes, Elisabeth M.; Michael, Robert T. 1977: An Economic Analysis of Marital Instability. In: Journal of Political Economy 85,6: 1141-1187.

Becker, Gary S. 1991: A Treatise on the Family. Harvard University Press.

Bernardi, Laura; Huinink, Johannes; Settersten, Richard A. 2019: The Life Course Cube: A Tool for Studying Lives. In: Advances in Life Course Research, Theoretical and Methodological Frontiers in Life Course Research 41: 100258. https://doi.org/10.1016/j.alcr.2018.11.004

Billari, Francesco C. 2015: Integrating Macro- and Micro-Level Approaches in the Explanation of Population Change. In: Population Studies 69, sup1: S11-S20. https://doi.org/10.1080/00324728.2015.1009712

Billari, Francesco C.; Liefbroer, Aart C. 2016: Why Still Marry? The Role of Feelings in the Persistence of Marriage as an Institution. In: The British Journal of Sociology 67,3: 516-540. https://doi.org/10.1111/1468-4446.12202

Billari, Francesco C.; Liefbroer, Aart C. 2010: Towards a New Pattern of Transition to Adulthood? In: Advances in Life Course Research, Demographic Perspectives on the Transition to Adulthood 15,2-3: 59-75. https://doi.org/10.1016/j.alcr.2010.10.003

Billari, Francesco C.; Liefbroer, Aart C. 2007: Should i Stay or Should i Go? The Impact of Age Norms on Leaving Home. In: Demography 44,1:181-198. https://doi.org/10.1353/dem.2007.0000

Blau, Peter M. 1994: Structural Contexts of Opportunities. University of Chicago Press.

Boertien, Diederik; Härkönen, Juho 2018: Why Does Women's Education Stabilize Marriages? The Role of Marital Attraction and Barriers to Divorce. In: Demographic Research 38,41: 1241-1276. https://doi.org/10.4054/DemRes.2018.38.41

Bracher, Michael; Santow, Gigi 1998: Economic Independence and Union Formation in Sweden. In: Population Studies 52,3: 275-294. https://doi.org/10.1080/0032472031000150466

Brown, Susan L. 2004: Moving from Cohabitation to Marriage: Effects on Relationship Quality. In: Social Science Research 33,1: 1-19. https://doi.org/10.1016/S0049-089X(03)00036-X

Brown, Susan L.; Booth, Alan 1996: Cohabitation versus Marriage: A Comparison of Relationship Quality. In: Journal of Marriage and Family 58,3: 668-678. https://doi.org/10.2307/353727 
Brown, Susan L. et al. 2019: Repartnering Following Gray Divorce: The Roles of Resources and Constraints for Women and Men. In: Demography 56,2: 503-523. https://doi.org/10.1007/s13524-018-0752-x

Brown, Susan L. et al. 2006: Links between Premarital Cohabitation and Subsequent Marital Quality, Stability, and Divorce: A Comparison of Covenant versus Standard Marriages. In: Social Science Research 35,2: 454-470. https://doi.org/10.1016/j.ssresearch.2006.03.001

Browning, Martin; Chiappori, Pierre-André; Weiss, Yoram 2014: Economics of the Family. Cambridge Surveys of Economic Literature. Cambridge: Cambridge University Press. https://doi.org/10.1017/CBO9781139015882

Brüderl, Josef 2010: Kausalanalyse Mit Paneldaten. In: Wolf, Christof; Best, Henning (Eds.): Handbuch der sozialwissenschaftlichen Datenanalyse. Wiesbaden: VS Verlag für Sozialwissenschaften: 963-994. https://doi.org/10.1007/978-3-531-92038-2_36

Brüderl, Josef; Kalter, Frank 2001: The Dissolution of Marriages: The Role of Information and Marital-specific Capital. In: The Journal of Mathematical Sociology 25,4: 403-421. https://doi.org/10.1080/0022250X.2001.9990262

Bumpass, Larry L.; Sweet, James A. 1989: National Estimates of Cohabitation. In: Demography 26,4: 615-625. https://doi.org/10.2307/2061261

Bumpass, Larry L.; Sweet, James A. 1972: Differentials in Marital Instability: 1970. In: American Sociological Review, 37,6: 754-766. https://doi.org/10.2307/2093585

Bumpass, Larry; Sweet, James; Martin, Teresa Castro 1990: Changing Patterns of Remarriage. In: Journal of Marriage and Family 52,3: 747-756. https://doi.org/10.2307/352939

Bunge, Mario 1979: Causality and Modern Science. Courier Corporation.

Casper, Lynne; Bianchi, Suzanne 2002: Continuity \& Change in the American Family. Thousand Oaks, California: SAGE Publications, Inc. https://doi.org/10.4135/9781452233871

Cherlin, Andrew 2017: Introduction to the Special Collection on Separation, Divorce, Repartnering, and Remarriage around the World. In: Demographic Research S21,38: 1275-1296. https://doi.org/10.4054/DemRes.2017.37.38

Cherlin, Andrew J. 2004: The Deinstitutionalization of American Marriage. In: Journal of Marriage and Family 66,4: 848-861. https://doi.org/10.1111/j.0022-2445.2004.00058.x

Clarkberg, Marin 1999: The Price of Partnering: The Role of Economic Well-Being in Young Adults' First Union Experiences. In: Social Forces 77,3: 945-968. https://doi.org/10.2307/3005967

Clarkberg, Marin; Stolzenberg, Ross M.; Waite, Linda J. 1995: Attitudes, Values, and Entrance into Cohabitational versus Martital Unions. In: Social Forces, 74, 2: 609-632. https://doi.org/10.2307/2580494

Cohan, Catherine L.; Kleinbaum, Stacey 2002: Toward a Greater Understanding of the Cohabitation Effect: Premarital Cohabitation and Marital Communication. In: Journa of Marriage and Family 64,1: 180-192. https://doi.org/10.1111/j.1741-3737.2002.00180.x

Cohen, Philip N.; Pepin, Joanna R. 2018: Unequal Marriage Markets: Sex Ratios and First Marriage among Black and White Women. In: Socius 4: 2378023118791084. https://doi.org/10.1177/2378023118791084

Coombs, Robert H. 1991: Marital Status and Personal Well-Being: A Literature Review. In: Family Relations 40,1: 97-102. https://doi.org/10.2307/585665 
Coulter, Rory; Hu, Yang 2017: Living Apart Together and Cohabitation Intentions in Great Britain. In: Journal of Family Issues 38,12: 1701-1729. https://doi.org/10.1177/0192513X15619461

Cox, Oliver C. 1940: Sex Ratio and Marital Status Among Negroes. In: American Sociological Review 5,6: 937-947. https://doi.org/10.2307/2084528

de Graaf, Paul M.; Kalmijn, Matthijs 2003: Alternative Routes in the Remarriage Market: Competing-Risk Analyses of Union Formation after Divorce. In: Social Forces 81,4: 1459-1498. https://doi.org/10.1353/sof.2003.0052

Di Giulio, Paola; Impicciatore, Roberto; Sironi, Maria 2019: The Changing Pattern of Cohabitation: A Sequence Analysis Approach. In: Demographic Research 40,42: 12111248. https://doi.org/10.4054/DemRes.2019.40.42

Diener, Ed et al. 2000: Similarity of the Relations between Marital Status and Subjective Well-Being across Cultures. In: Journal of Cross-Cultural Psychology 31,4: 419-436. https://doi.org/10.1177/0022022100031004001

Dorbritz, Jürgen; Naderi, Robert 2012: Stability of Bilocal Relationships - Conditions and Development Paths. An Analysis of the First and Second Wave of Pairfam. In: Comparative Population Studies 37,3-4: 429-462. https://doi.org/10.12765/CPoS-2012-08

Dush, Claire M. Kamp; Cohan, Catherine L.; Amato, Paul R. 2003: The Relationship between Cohabitation and Marital Quality and Stability: Change across Cohorts? In: Journal of Marriage and Family 65,3: 539-549. https://doi.org/10.1111/j.1741-3737.2003.00539.x

Duvander, Ann-Zofie; Kridahl, Linda 2020: Decisions on Marriage? Couples' Decisions on Union Transition in Sweden. In: Genus 76,22. https://doi.org/10.1186/s41118-020-00092-5

Dykstra, Pearl A.; Poortman, Anne-Rigt 2010: Economic Resources and Remaining Single: Trends Over Time. In: European Sociological Review 26,3: 277-290. https://doi.org/10.1093/esr/jcp021

Eckhard, Jan; Stauder, Johannes 2019: Partner Market Opportunities and Union Formation over the Life Course - A Comparison of Different Measures. In: Population, Space and Place 25,4: e2178. https://doi.org/10.1002/psp.2178

Elzinga, Cees H.; Liefbroer, Aart C. 2007: De-Standardization of Family-Life Trajectories of Young Adults: A Cross-National Comparison Using Sequence Analysis: DéStandardisation Des Trajectoires de Vie Familiale Des Jeunes Adultes: Comparaison Entre Pays Par Analyse Séquentielle. In: European Journal of Population / Revue Européenne de Démographie 23,3-4: 225-250. https://doi.org/10.1007/s10680-007-9133-7

Esping-Andersen, Gøsta; Billari, Francesco C. 2015: Re-Theorizing Family Demographics. In: Population and Development Review 41,1: 1-31. https://doi.org/10.1111/j.1728-4457.2015.00024.x

Filser, Andreas; Preetz, Richard 2021: Do Local Sex Ratios Approximate Subjective Partner Markets? In: Human Nature 32: 406-433. https://doi.org/10.1007/s12110-021-09397-6

Finn, Christine; Johnson, Matthew D.; Neyer, Franz J. 2020: Happily (n)Ever after? Codevelopment of Romantic Partners in Continuing and Dissolving Unions. In: Developmental Psychology 56,5: 1022-1028. https://doi.org/10.1037/dev0000897 
Fossett, Mark A.; Kiecolt, K. Jill 1991: A Methodological Review of the Sex Ratio: Alternatives for Comparative Research. In: Journal of Marriage and Family 53,4: 941957. https://doi.org/10.2307/352999

Fulda, Barbara Elisabeth 2016: The Diversity in Longitudinal Partnership Trajectories during the Transition to Adulthood: How is it Related to Individual Characteristics and Regional Living Conditions? In: Demographic Research 35,37: 1101-1134. https://doi.org/10.4054/DemRes.2016.35.37

Gałęzewska, Paulina; Perelli-Harris, Brienna; Berrington, Ann 2017: Cross-National Differences in Women's Repartnering Behaviour in Europe: The Role of Individual Demographic Characteristics. In: Demographic Research 37,8: 189-228. https://doi.org/10.4054/DemRes.2017.37.8

Gattig, Alexander; Minkus, Lara 2021: Does Marriage Increase Couples' Life Satisfaction? In: Comparative Population Studies 46: 123-148. https://doi.org/10.12765/CPoS-2021-05

Goldscheider, Frances; Bernhardt, Eva; Lappegård, Trude 2015: The Gender Revolution: A Framework for Understanding Changing Family and Demographic Behavior. In: Population and Development Review 41,2: 207-239. https://doi.org/10.1111/j.1728-4457.2015.00045.x

Gonalons-Pons, Pilar; Schwartz, Christine R. 2017: Trends in Economic Homogamy: Changes in Assortative Mating or the Division of Labor in Marriage? In: Demography 54,3: 985-1005. https://doi.org/10.1007/s13524-017-0576-0

Goode, William Josiah 1956: After Divorce. New York: Free Press.

Groves, Ernest Rutherford; Ogburn, William Fielding 1928: American Marriage and Family Relationships. H. Holt.

Härkönen, Juho 2014: Divorce: Trends, Pattern, Causes, and Consequences. In: Treas, Judith; Scott, Jacqueline; Richards, Martin (Eds.): The Wiley Blackwell Companion to the Sociology of Families: 303-322.

Härkönen, Juho; Dronkers, Jaap 2006: Stability and Change in the Educational Gradient of Divorce. A Comparison of Seventeen Countries. In: European Sociological Review 22,5: 501-517. https://doi.org/10.1093/esr/jcl011

Haskey, John 2005: Living arrangements in contemporary Britain: Having a partner who usually lives elsewhere and Living Apart Together (LAT). In: Population Trends 122: 35-45.

Heuveline, Patrick; Timberlake, Jeffrey M.; Furstenberg, Frank F. 2003: Shifting Childrearing to Single Mothers: Results from 17 Western Countries. In: Population and Development Review 29,1: 47-71. https://doi.org/10.1111/j.1728-4457.2003.00047.x

Hiekel, Nicole; Liefbroer, Aart C.; Poortman, Anne-Rigt 2014: Understanding Diversity in the Meaning of Cohabitation Across Europe. In: European Journal of Population 30,4: 391-410. https://doi.org/10.1007/s10680-014-9321-1

Impicciatore, Roberto; Billari, Francesco C. 2012: Secularization, Union Formation Practices, and Marital Stability: Evidence from Italy. In: European Journal of Population / Revue Européenne de Démographie 28,2: 119-138. https://doi.org/10.1007/s10680-012-9255-4

Ishizuka, Patrick 2018: The Economic Foundations of Cohabiting Couples' Union Transitions. In: Demography 55,2: 535-557. https://doi.org/10.1007/s13524-018-0651-1 
Ivanova, Katya; Kalmijn, Matthijs; Uunk, Wilfred 2013: The Effect of Children on Men's and Women's Chances of Re-Partnering in a European Context. In: European Journal of Population / Revue Européenne de Démographie 29,4: 417-444. https://doi.org/10.1007/s10680-013-9294-5

Jalovaara, Marika 2012: Socio-Economic Resources and First-Union Formation in Finland, Cohorts Born 1969-81. In: Population Studies 66,1: 69-85. https://doi.org/10.1080/00324728.2011.641720

Jalovaara, Marika 2013: Socioeconomic Resources and the Dissolution of Cohabitations and Marriages. In: European Journal of Population / Revue Européenne de Démographie 29,2: 167-193. https://doi.org/10.1007/s10680-012-9280-3

Jalovaara, Marika; Fasang, Anette 2015: Are There Gender Differences in Family Trajectories by Education in Finland? In: Demographic Research 33,44: 1241-1256. https://doi.org/10.4054/DemRes.2015.33.44

Jalovaara, Marika; Kulu, Hill 2018: Separation Risk over Union Duration: An Immediate Itch? In: European Sociological Review 34,5: 486-500. https://doi.org/10.1093/esr/jcy017

James, Spencer L.; Beattie, Brett A. 2012: Reassessing the Link between Women's Premarital Cohabitation and Marital Quality. In: Social Forces 91,2: 635-662. https://doi.org/10.1093/sf/sos126

Jaschinski, Ina 2011: Der Übergang in Eine Nacheheliche Partnerschaft: Eine vergleichende Analyse zwischen Männern und Frauen auf Basis des deutschen Generations and Gender Survey: In: Journal of Family Research 23,2: 219-240. https://doi.org/10.20377/jfr-208

Johnson, Matthew D.; Horne, Rebecca M. 2016: Temporal Ordering of Supportive Dyadic Coping, Commitment, and Willingness to Sacrifice. In: Family Relations 65,2: 314-326. https://doi.org/10.1111/fare.12187

Jose, Anita; O'Leary, K. Daniel; Moyer, Anne 2010: Does Premarital Cohabitation Predict Subsequent Marital Stability and Marital Quality? A Meta-Analysis. In: Journal of Marriage and Family 72,1: 105-116. https://doi.org/10.1111/j.1741-3737.2009.00686.x

Kalmijn, Matthijs 2011: The Influence of Men's Income and Employment on Marriage and Cohabitation: Testing Oppenheimer's Theory in Europe. In: European Journal of Population / Revue Européenne de Démographie 27,3: 269-293. https://doi.org/10.1007/s10680-011-9238-x

Kalmijn, Matthijs 2013: The Educational Gradient in Marriage: A Comparison of 25 European Countries. In: Demography 50,4: 1499-1520. https://doi.org/10.1007/s13524-013-0229-x

Kenny, David A.; Kashy, Deborah A.; Cook, William L. 2006: Dyadic Data Analysis. Dyadic Data Analysis. New York: Guilford Press.

Klein, Thomas 1990: Wiederheirat nach Scheidung in der Bundesrepublik: Eine empirische Überprüfung bislang vorliegender Theorieansätze aus der Perspektive des Lebensverlaufs. In: Kölner Zeitschrift für Soziologie und Sozialpsychologie 42,1: 60-80.

Kline, Galena H. et al. 2004: Timing Is Everything: Pre-Engagement Cohabitation and Increased Risk for Poor Marital Outcomes. In: Journal of Family Psychology: 18,2: 311 318. https://doi.org/10.1037/0893-3200.18.2.311

Konietzka, Dirk; Tatjes, André 2014: Two Steps of Union Formation: First Intimate Relationships and First Coresidential Unions in the Life Courses of the German Cohorts 1971-1973 and 1981-1983. In: Journal of Youth Studies 17,8: 1077-1096. https://doi.org/10.1080/13676261.2014.888405 
Krapf, Sandra 2018: Moving in or Breaking Up? The Role of Distance in the Development of Romantic Relationships. In: European Journal of Population 34,3: 313-336. https://doi.org/10.1007/s10680-017-9428-2

Kulu, Hill; Boyle, Paul 2010: Premarital Cohabitation and Divorce: Support for the "Trial Marriage" Theory? In: Demographic Research 23,31: 879-904.

https://doi.org/10.4054/DemRes.2010.23.31

Kuperberg, Arielle 2014: Age at Coresidence, Premarital Cohabitation, and Marriage Dissolution: 1985-2009. In: Journal of Marriage and Family 76,2: 352-369. http://dx.doi.org/10.1111/jomf.12092

Lesthaeghe, Ron 1995: The second demographic transition in western countries: An interpretation. In: Mason Oppenheim, Karen; Jensen, An-Magritt (Eds.): Gender and Family Change in Industrialized Countries. Oxford: Clarendon Press: 17-62.

Lesthaeghe, Ron 2010: The Unfolding Story of the Second Demographic Transition. In: Population and Development Review 36,2: 211-251. https://doi.org/10.1111/j.1728-4457.2010.00328.x

Lichter, Daniel T.; Qian, Zhenchao; Mellott, Leanna M. 2006: Marriage or Dissolution? Union Transitions among Poor Cohabiting Women. In: Demography 43,2: 223-240. https://doi.org/10.1353/dem.2006.0016

Lieberwirth, Claudia; Wang, Zuoxin 2014: Social Bonding: Regulation by Neuropeptides. In: Frontiers in Neuroscience 8. https://doi.org/10.3389/fnins.2014.00171

Liefbroer, Aart. C. 2005: Transition from youth to adulthood in the Netherlands. In: Blossfeld, Hans-Pater et al. (Eds.): Globalization, uncertainty and youth in society. London: Routledge: 83-104.

Liefbroer, Aart C.; Billari, Francesco C. 2010: Bringing Norms Back in: A Theoretical and Empirical Discussion of Their Importance for Understanding Demographic Behaviour. In: Population, Space and Place 16,4: 287-305. https://doi.org/10.1002/psp.552

Liefbroer, Aart C.; Poortman, Anne-Rigt; Seltzer, Judith 2015: Why Do Intimate Partners Live Apart? Evidence on LAT Relationships across Europe. In: Demographic Research 32,8: 251-286. https://doi.org/10.4054/DemRes.2015.32.8

Lois, Daniel; Lois, Nadia 2012: "Living apart together" - eine dauerhafte Alternative? In: Soziale Welt 63,2: 117-140. https://doi.org/10.5771/0038-6073-2012-2-117

Lundberg, Shelly; Pollak, Robert A.; Stearns, Jenna 2016: Family Inequality: Diverging Patterns in Marriage, Cohabitation, and Childbearing. In: Journal of Economic Perspectives 30,2: 79-102. https://doi.org/10.1257/jep.30.2.79

Manning, Wendy D.; Brown, Susan L.; Payne, Krista K. 2014: Two Decades of Stability and Change in Age at First Union Formation: Stability and Change in Age at First Union. In: Journal of Marriage and Family 76,2: 247-260. https://doi.org/10.1111/jomf.12090

Manning, Wendy D.; Cohen, Jessica A. 2012: Premarital Cohabitation and Marital Dissolution: An Examination of Recent Marriages. In: Journal of Marriage and Family 74,2: 377-387. https://doi.org/10.1111/j.1741-3737.2012.00960.x

Manning, Wendy D.; Smock, Pamela J. 2005: Measuring and Modeling Cohabitation: New Perspectives From Qualitative Data. In: Journal of Marriage and Family 67,4: 989 1002. https://doi.org/10.1111/j.1741-3737.2005.00189.x

Matysiak, Anna; Styrc, Marta; Vignoli, Daniele 2014: The Educational Gradient in Marital Disruption: A Meta-Analysis of European Research Findings. In: Population Studies 68,2: 197-215. https://doi.org/10.1080/00324728.2013.856459

Mayer, Karl Ulrich 2009: New Directions in Life Course Research. In: Annual Review of Sociology 35,1: 413-433. https://doi.org/10.1146/annurev.soc.34.040507.134619 
McLanahan, Sara; Casper, Lynne 1995: Growing diversity and inequality in the American family. In: Farley, Reynolds (Ed.): State of the Union: America in the 1990s. Volume 2. New York: Russell Sage Found: 1-46.

Milan, Anne; Peters, Alice 2003: Couples living apart. In: Canadian Social Trends 11,008: 2-6.

Musick, Kelly; Bumpass, Larry 2012: Reexamining the Case for Marriage: Union Formation and Changes in Well-Being. In: Journal of Marriage and Family 74,1: 1-18. https://doi.org/10.1111/j.1741-3737.2011.00873.x

Oláh, Livia Sz.; Karlsson, Lena; Sandström, Glenn 2020: Committed to independence? An exploratory study of living-apart-together (LAT) in contemporary Sweden. In: Stockholm Research Reports in Demography 34.

Opp, Karl-Dieter 2010: Kausalität als Gegenstand der Sozialwissenschaften und der multivariaten Statistik. In: Wolf, Christof; Best, Henning (Eds.): Handbuch der sozialwissenschaftlichen Datenanalyse. Wiesbaden: VS Verlag für Sozialwissenschaften: 9-38. https://doi.org/10.1007/978-3-531-92038-2_2

Oppenheimer, Valerie Kincade 1988: A Theory of Marriage Timing. In: American Journal of Sociology 94,3: 563-591. https://doi.org/10.1086/229030

Oppenheimer, Valerie Kincade 1997: Women's Employment and the Gain to Marriage: The Specialization and Trading Model. In: Annual Review of Sociology 23,1: 431-453. https://doi.org/10.1146/annurev.soc.23.1.431

Oppenheimer, Valerie Kincade 2003: Cohabiting and Marriage during Young Men's CareerDevelopment Process. In: Demography 40,1: 127-149. https://doi.org/10.2307/3180815

Oppenheimer, Valerie. K.; Lew, Vivian 1995: American marriage formation in the eighties: How important waswomen's economic independence? In: Oppenheim Mason, Karen; Jensen, An-Magritt (Eds.): Gender and Family change in industrialized countries. Oxford. Clarendon Press: 105-138.

Pasteels, Inge; Lyssens-Danneboom, Vicky; Mortelmans, Dimitri 2017: A Life Course Perspective on Living Apart Together: Meaning and Incidence Across Europe. In: Social Indicators Research 130,2: 799-817. https://doi.org/10.1007/s11205-015-1189-x

Pasteels, Inge; Mortelmans, Dimitri 2017: The Socioeconomic Determinants of Repartnering after Divorce or Separation in Belgium. In: Demographic Research 36,58: 1785-1812. https://doi.org/10.4054/DemRes.2017.36.58

Pearl, Judea 2000: Causality: Models, Reasoning, and Inference. New York: Cambridge University Press.

Pearl, Judea; Glymour, Madelyn; Jewell, Nicholas P. 2019: Causal Inference in Statistics. Sussex: Wiley.

Perelli-Harris, Brienna; Amos, Mark 2015: Changes in Partnership Patterns across the Life Course: An Examination of 14 Countries in Europe and the United States. In: Demographic Research 33: 145-178. https://doi.org/10.4054/DemRes.2015.33.6

Perelli-Harris, Brienna et al. 2017: The Rise in Divorce and Cohabitation: Is There a Link? In: Population and Development Review 43,2: 303-329. https://doi.org/10.1111/ padr.12063

Perelli-Harris, Brienna; Styrc, Marta 2018: Mental Well-Being Differences in Cohabitation and Marriage: The Role of Childhood Selection. In: Journal of Marriage and Family 80,1: 239-255. https://doi.org/10.1111/jomf.12431

Poortman, Anne-Rigt 2007: The First Cut Is the Deepest? The Role of the Relationship Career for Union Formation. In: European Sociological Review 23,5: 585-598. https://doi.org/10.1093/esr/jcm024 
Raley, R. Kelly; Sweeney, Megan M. 2020: Divorce, Repartnering, and Stepfamilies: A Decade in Review. In: Journal of Marriage and Family 82,1: 81-99. https://doi.org/10.1111/jomf.12651

Rapp, Ingmar 2018: Partnership Formation in Young and Older Age. In: Journal of Family Issues 39,13: 3363-3390. https://doi.org/10.1177/0192513X18783469

Régnier-Loilier, Arnaud 2016: Partnership Trajectories of People in Stable Non-Cohabiting Relationships in France. In: Demographic Research 35: 1169-1212. https://doi.org/10.4054/DemRes.2016.35.40

Regnier-Loilier, Arnaud; Beaujouan, Éva; Villeneuve-Gokalp, Catherine 2009: Neither Single, nor in a Couple. A Study of Living Apart Together in France. In: Demographic Research 21: 75-108. https://doi.org/10.4054/DemRes.2009.21.4

Reimondos, Anna; Evans, Ann; Gray, Edith 2011: Living-Apart-Together (LAT) Relationships in Australia. In: Family Matters 87: 43-55.

Rhoades, Galena K.; Stanley, Scott M.; Markman, Howard J. 2009: Couples' Reasons for Cohabitation: Associations With Individual Well-Being and Relationship Quality. In: Journal of Family Issues 30,2: 233-258. https://doi.org/10.1177/0192513X08324388

Rhoades, Galena K.; Stanley, Scott M.; Markman, Howard J. 2012: A Longitudinal Investigation of Commitment Dynamics in Cohabiting Relationships. In: Journal of Family Issues 33,3: 369-390. https://doi.org/10.1177/0192513X11420940

Rindfuss, Ronald R.; VandenHeuvel, Audrey 1990: Cohabitation: A Precursor to Marriage or an Alternative to Being Single? In: Population and Development Review 16,4: 703726. https://doi.org/10.2307/1972963

Robert, Peter; Bukodi, Erzsebet 2005: The effects of the globalization process on the transition to adulthood in Hungary. In: Blossfeld, Hans-Pater et al. (Eds.): Globalization, uncertainty and youth in society. London: Routledge: 177-214.

Rosenfeld, Michael J.; Roesler, Katharina 2019: Cohabitation Experience and Cohabitation's Association With Marital Dissolution. In: Journal of Marriage and Family 81,1: 42-58. https://doi.org/10.1111/jomf.12530

Sassler, Sharon 2010: Partnering Across the Life Course: Sex, Relationships, and Mate Selection. In: Journal of Marriage and Family 72,3: 557-575. https://doi.org/10.1111/j.1741-3737.2010.00718.x

Sassler, Sharon; Lichter, Daniel T. 2020: Cohabitation and Marriage: Complexity and Diversity in Union-Formation Patterns. In: Journal of Marriage and Family 82,1: 35-61. https://doi.org/10.1111/jomf.12617

Sassler, Sharon; Michelmore, Katherine; Holland, Jennifer A. 2016: The Progression of Sexual Relationships. In: Journal of Marriage and Family 78,3: 587-597. https://doi.org/10.1111/jomf.12289

Sassler, Sharon; Michelmore, Katherine; Qian, Zhenchao 2018: Transitions From Sexual Relationships Into Cohabitation and Beyond. In: Demography 55,2: 511-534. https://doi.org/10.1007/s13524-018-0649-8

Sassler, Sharon; Miller, Amanda J. 2011: Class Differences in Cohabitation Processes. In: Family Relations 60,2: 163-177. https://doi.org/10.1111/j.1741-3729.2010.00640.x

Sassler, Sharon; Miller, Amanda Jayne 2017: Cohabitation Nation: Gender, Class, and the Remaking of Relationships. 1st. ed. University of California Press [https://www. jstor.org/stable/10.1525/j.ctt1qft08h, 04.08.2021].

Sayer, Liana C. et al. 2011: She Left, He Left: How Employment and Satisfaction Affect Men's and Women's Decisions to Leave Marriages. In: Ajs; American Journal of Sociology 116,6: 1982-2018. https://doi.org/10.1086/658173 
Schacht, Ryan; Kramer, Karen L. 2016: Patterns of Family Formation in Response to Sex Ratio Variation. In: PLOS ONE 11,8: e0160320. https://doi.org/10.1371/journal.pone.0160320

Schnor, Christine 2015: Does Waiting Pay off for Couples?: Partnership Duration Prior to Household Formation and Union Stability. In: Demographic Research 33: 611-652. https://doi.org/10.4054/DemRes.2015.33.22

Schnor, Christine; Pasteels, Inge; Bavel, Jan Van 2017: Sole Physical Custody and Mother's Repartnering After Divorce. In: Journal of Marriage and Family 79,3: 879. 890. https://doi.org/10.1111/jomf.12389

Schwartz, Christine R.; Gonalons-Pons, Pilar 2016: Trends in Relative Earnings and Marital Dissolution: Are Wives Who Outearn Their Husbands Still More Likely to Divorce? In: RSF: The Russell Sage Foundation Journal of the Social Sciences 2,4: 218-236. https://doi.org/10.7758/rsf.2016.2.4.08

Smock, Pamela J. 2000: Cohabitation in the United States: An Appraisal of Research Themes, Findings, and Implications. In: Annual Review of Sociology 26,1: 1-20. https://doi.org/10.1146/annurev.soc.26.1.1

Sobotka, Tomáš; Toulemon, Laurent 2008: Overview Chapter 4: Changing Family and Partnership Behaviour: Common Trends and Persistent Diversity across Europe. In: Demographic Research 19,6: 85-138. https://doi.org/10.4054/DemRes.2008.19.6

Soons, Judith P.M.; Liefbroer, Aart C.; Kalmijn, Matthijs 2009: The Long-Term Consequences of Relationship Formation for Subjective Well-Being. In: Journal of Marriage and Family 71,5: 1254-1270. https://doi.org/10.1111/j.1741-3737.2009.00667.x

Soons, Judith P.M.; Kalmijn, Matthijs 2009: Is Marriage More than Cohabitation? WellBeing Differences in 30 European Countries. In: Journal of Marriage and Family 71,5: 1141-1157. https://doi.org/10.1111/j.1741-3737.2009.00660.x

South, Scott J.; Lloyd, Kim M. 1992: Marriage Opportunities and Family Formation: Further Implications of Imbalanced Sex Ratios. In: Journal of Marriage and Family 54,2: 440-451. https://doi.org/10.2307/353075

South, Scott J.; Trent, Katherine; Shen, Yang 2001: Changing Partners: Toward a Macrostructural-Opportunity Theory of Marital Dissolution. In: Journal of Marriage and Family 63,3: 743-754. https://doi.org/10.1111/j.1741-3737.2001.00743.x

Spirtes, Peter; Glymour, Clark; Scheines, Richard 1993: Causation, Prediction, and Search. Lecture Notes in Statistics. New York: Springer-Verlag. https://doi.org/10.1007/978-1-4612-2748-9

Stafford, Laura; Kline, Susan L.; Rankin, Caroline T. 2004: Married Individuals, Cohabiters, and Cohabiters Who Marry: A Longitudinal Study of Relational and Individual WellBeing. In: Journal of Social and Personal Relationships 21,2: 231-248. https://doi.org/10.1177/0265407504041385

Stanley, Scott M.; Rhoades, Galena K.; Whitton, Sarah W. 2010: Commitment: Functions, Formation, and the Securing of Romantic Attachment. In: Journal of Family Theory \& Review 2,4: 243-257. https://doi.org/10.1111/j.1756-2589.2010.00060.x

Stanley, Scott M.; Rhoades, Galena Kline; Markman, Howard J. 2006: Sliding Versus Deciding: Inertia and the Premarital Cohabitation Effect. In: Family Relations 55,4: 499-509. https://doi.org/10.1111/j.1741-3729.2006.00418.x

Stanley, Scott M.; Whitton, Sarah W.; Markman, Howard J. 2004: Maybe I Do: Interpersonal Commitment and Premarital or Nonmarital Cohabitation. In: Journal of Family Issues 25,4: 496-519. https://doi.org/10.1177/0192513X03257797 
Stauder, Johannes 2008: Opportunitäten und Restriktionen des Kennenlernens: Zur sozialen Vorstrukturierung der Kontaktgelegenheiten am Beispiel des Partnermarkts. In: KZfSS Kölner Zeitschrift für Soziologie und Sozialpsychologie 60,2: 266-286. https://doi.org/10.1007/s11577-008-0016-7

Strohm, Charles et al. 2009: "Living Apart Together" Relationships in the United States. In: Demographic Research 21,7: 177-214. https://doi.org/10.4054/DemRes.2009.21.7

Sweet, James A. 1973: Differentials in Remarriages Probabilities. Center for Demography and Ecology Working Paper 73-8. University of Wisconsin: Center for Demography and Ecology.

Teachman, Jay 2010: Wives' Economic Resources and Risk of Divorce. In: Journal of Family Issues 31,10: 1305-1323. https://doi.org/10.1177/0192513X10370108

Teachman, Jay D.; Heckert, Alex 1985: The Impact of Age and Children on Remarriage: Further Evidence. In: Journal of Family Issues 6,2: 185-203.

https://doi.org/10.1177/019251385006002003

Trovato, Frank 1988: A Macrosociological Analysis of Change in the Marriage Rate: Canadian Women, 1921-25 to 1981-85. In: Journal of Marriage and the Family 50,2: 507-521. https://doi.org/10.2307/352016

Udry, J. Richard 1966: Marital Instability by Race, Sex, Education, and Occupation Using 1960 Census Data. In: American Journal of Sociology 72,2: 203-209. https://doi.org/10.1086/224279

Umberson, Debra et al. 2005: As Good as It Gets? A Life Course Perspective on Marital Quality. In: Social Forces 84,1: 493-511. https://doi.org/10.1353/sof.2005.0131

Van De Kaa, D.J. 1987: Europe's Second Demographic Transition. In: Population Bulletin 42,1: 1-59.

Vanassche, Sofie et al. 2015: Repartnering and Childbearing After Divorce: Differences According to Parental Status and Custodial Arrangements. In: Population Research and Policy Review 34,5: 761-784. https://doi.org/10.1007/s11113-015-9366-9

Vespa, Jonathan; Painter, Matthew A. 2011: Cohabitation History, Marriage, and Wealth Accumulation. In: Demography 48,3: 983-1004. https://doi.org/10.1007/s13524-011-0043-2

Wagner, Michael et al. 2019: The Transition from Living Apart Together to a Coresidential Partnership. In: Advances in Life Course Research 39: 77-86. https://doi.org/10.1016/j.alcr.2018.12.002

Warner, Tara D. et al. 2011: Relationship Formation and Stability in Emerging Adulthood: Do Sex Ratios Matter? In: Social Forces 90,1: 269-295. https://doi.org/10.1093/sf/90.1.269

Woodward, James 2003: Making Things Happen: A Theory of Causal Explanation. Making Things Happen. https://doi.org/10.1093/0195155270.001.0001

Xie, Yu et al. 2003: Economic Potential and Entry into Marriage and Cohabitation. In: Demography 40,2: 351-367. https://doi.org/10.2307/3180805

Yurkiw, Jennifer; Johnson, Matthew D. 2021: Perceived Stress, Supportive Dyadic Coping, and Sexual Communication in Couples. In: Journal of Social and Personal Relationships 38,5: 1729-1737. https://doi.org/10.1177/0265407521996446

Zimmermann, Anke C.; Easterlin, Richard A. 2006: Happily Ever After? Cohabitation, Marriage, Divorce, and Happiness in Germany. In: Population and Development Review 32,3: 511-528. https://doi.org/10.1111/j.1728-4457.2006.00135.x 
Prof. Dr. Michael Feldhaus ( $\varangle)$. Carl von Ossietzky Universität Oldenburg, Institute for Social Sciences. Oldenburg, Germany. E-mail: michael.feldhaus@uni-oldenburg.de URL: https://uol.de/en/school1/institute-for-social-sciences/sociology-of-the-lifecourse-and-social-inequality/team/michael-feldhaus

Richard Preetz. University of Bremen, SOCIUM Research Center on Inequality and Social Policy. Bremen, Germany. E-mail: rpreetz@uni-bremen.de

URL: https://www.socium.uni-bremen.de/about-the-socium/members/richard-preetz/ Carl von Ossietzky Universität Oldenburg, Institute for Social Sciences. Oldenburg, Germany. E-mail: richard.preetz@uni-oldenburg.de

URL: https://uol.de/en/school1/institute-for-social-sciences/sociology-of-the-lifecourse-and-social-inequality/team/richard-preetz 


\section{Comparative Population Studies}

WWW.comparativepopulationstudies.de

ISSN: 1869-8980 (Print) - 1869-8999 (Internet)

\section{Published by}

Prof. Dr. Norbert F. Schneider

Federal Institute for Population Research D-65180 Wiesbaden / Germany

\section{(c) BY-SA}

2021

\section{Managing Editor}

Prof. Dr. Johannes Huinink

Dr. Katrin Schiefer

\section{Editorial Assistant}

Beatriz Feiler-Fuchs

Wiebke Hamann

\section{Layout}

Beatriz Feiler-Fuchs

E-mail:cpos@bib.bund.de

\section{Scientific Advisory Board}

Karsten Hank (Cologne)

Michaela Kreyenfeld (Berlin)

Marc Luy (Vienna)

Natalie Nitsche (Rostock)

Zsolt Spéder (Budapest)

Rainer Wehrhahn (Kiel)

\section{Board of Reviewers}

Bruno Arpino (Barcelona)

Kieron Barclay (Rostock)

Laura Bernardi (Lausanne)

Gabriele Doblhammer (Rostock)

Anette Eva Fasang (Berlin)

Michael Feldhaus (Oldenburg)

Tomas Frejka (Sanibel)

Alexia Fürnkranz-Prskawetz (Vienna)

Birgit Glorius (Chemnitz)

Fanny Janssen (Groningen)

Frank Kalter (Mannheim)

Stefanie Kley (Hamburg)

Bernhard Köppen (Koblenz)

Anne-Kristin Kuhnt (Duisburg)

Hill Kulu (St Andrews)

Nadja Milewski (Wiesbaden)

Roland Rau (Rostock)

Thorsten Schneider (Leipzig)

Tomas Sobotka (Vienna)

Jeroen J. A. Spijker (Barcelona)

Heike Trappe (Rostock)

Helga de Valk (The Hague)

Sergi Vidal (Barcelona)

Michael Wagner (Cologne) 